International Journal of Life Sciences
Available online at http://sciencescholar.us/journal/index.php/ijls
Vol. 3 No. 1, April 2019, pages: $41 \sim 47$
e-ISSN: 2550-6986, p-ISSN: $2550-6994$
https://doi.org/10.29332/ijls.v3n1.257

\title{
Recovery of Ancestral Knowledge of the Use of Leaf and Bark towards Royal Ceibo
}

\author{
(1) corsshatk \\ Telly Yarita Macias Zambrano a , Odalis Paola Gorozabel Vera ${ }^{b}$, Carmen Liliana Mera Plaza $^{c}$,
Ricardo Munoz Farfan ${ }^{\mathrm{d}}$
}

Article history: Received 18 July 2018, Accepted: 31 December 2018, Published: 18 March 2019

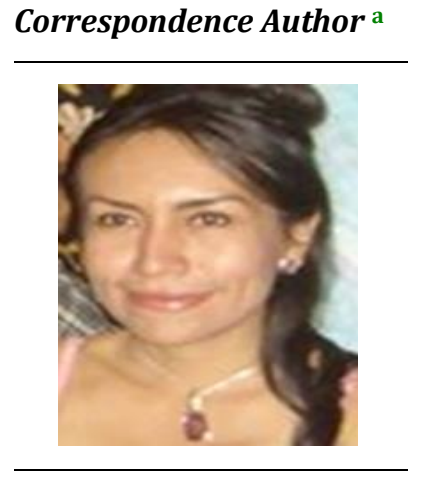

Keywords

ancestral;

bark;

leaf;

recovery;

royal ceibo;

\begin{abstract}
The ancestral knowledge regarding the use of the leaves and bark of the ceibo to heal wounds, sores, blisters and control the bleeding of wounds by cuts, is a practice that has been lost especially in the rural and marginal urban area of the Portoviejo canton, being this way we worked in the recovery of the ancestral knowledge regarding the use of the leaf and bark of the royal ceibo tree, using the experimental method to elaborate the remedy and the plaster, a qualitative research was applied through an interview 3 farmers who have ancestral knowledge about remedies based on royal ceibo. The results include the recovery of ancestral knowledge to develop a remedy healing wounds, sores, blisters, and bleeding controller, tested on 30 students who performed agricultural practices in the field, exposed to the sun and heavy work in the field, with cuts and minor injuries, in which the remedy was applied based on cooked leaves of ceibo, and in 2 cases of wounds with bleeding the remedy of leaves and a bark plaster was applied, managing to stop the bleeding with the washing and promoting the healing of the wounds.
\end{abstract}

e-ISSN: 2550-6986, p-ISSN: 2550-6994@C Copyright 2019. The Author. SS Journals Published by Universidad Técnica de Manabí. This is an open-access article under the CC BY-SA 4.0 license (https://creativecommons.org/licenses/by-sa/4.0/) All rights reserved.

\section{Contents}

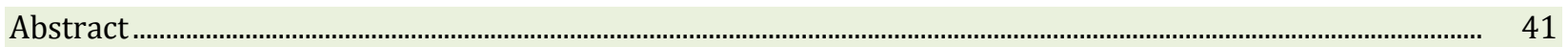

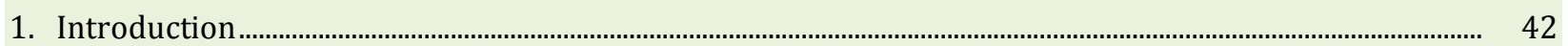

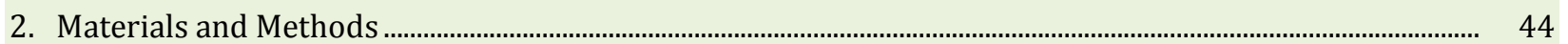

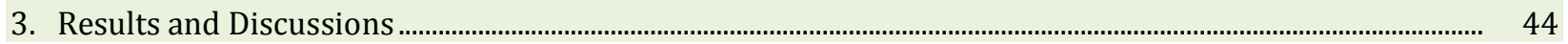

a Master in Agricultural Engineering, Professor at the Higher Technological Institute Paulo Emilio Macias, Portoviejo, Manabi, Ecuador

b Student of the fourth semester of the career of Superior Technology in Agriculture at the Higher Technological Institute Paulo Emilio Macias, Portoviejo, Manabi, Ecuador

c Bachelor of Accounting and Auditing, Higher Technological Institute Paulo Emilio Macias, Portoviejo, Manabi, Ecuador

d Mechanical Engineer, Higher Technological Institute Paulo Emilio Macias, Portoviejo, Manabi, Ecuador 


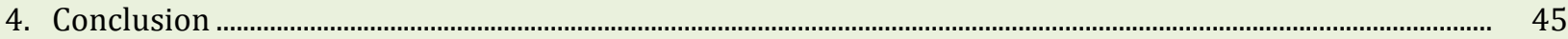

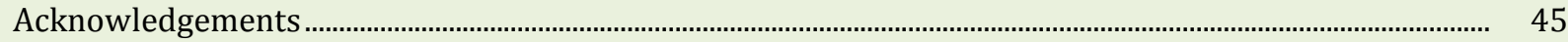

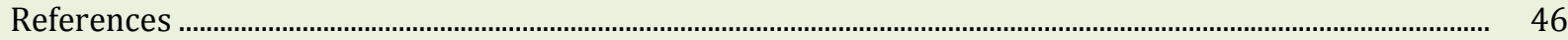

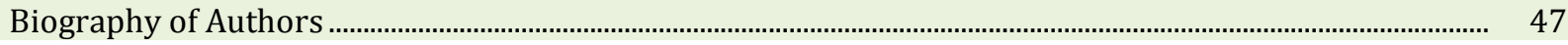

\section{Introduction}

The ancestral knowledge regarding the use of the leaves and bark of the ceibo to heal wounds, sores, blisters and control the bleeding of wounds by cuts, has decreased especially in the rural and marginal urban area of Portoviejo canton. The main objective of the research is the recovery of ancestral knowledge regarding the use of the leaf and bark of the royal ceibo tree. It has been hypothesized that the ancestral knowledge inherent to the use of the leaf and bark of the royal ceibo tree can be recovered.

Some terminologies used are Remedy: pharmacological substance created for medicinal purposes to reduce the symptoms of a disease or alter a certain physiological condition. Plaster: Thick, sticky substance that extends over a piece of cloth and is applied, for therapeutic purposes, on the part of the body that is sick. It is concluded that the scarce application of ancestral knowledge in terms of functional remedies based on leaves and tree bark of royal ceibo, and the recovery of ancestral knowledge on the preparation and use of these.

In the city of Portoviejo, the typical tropical dry forest species have been found, in which, due to their height and bulky stem, the Ceiba pentandra ceibo stands out, as well as other trees that are characterized by their abundance and because they are always green. same that together with other found species are characteristic of these kinds of forest. (Pico, 2010)

Erythrina L. is a genus of the Phaseoleae Tribe of pantropical distribution, composed of approximately 120 species of trees and non-fickle shrubs, 20 grow in South America. Because of its unique characteristics within the Tribe as glandular stipelamps, basic chromosome number equal to 21, complex isoquinolinic alkaloids, pollen pored with thick endexine and idioblasts in the palisade, among others, it has been suggested that the species of the genus should be part of an independent subtribe (Lozano \& Zapater, 2010).

The use of medicinal plants for healing purposes is a practice that has been used for thousands of years. For a long time natural remedies, especially medicinal plants, were the main and even the only therapeutic resource available. This made it possible to deepen the knowledge of plant species that possess medicinal properties and to expand the experience in the use of the products extracted from them. 1. In modern medicine, a quarter of the substances are of origin vegetable, for a total of 4500 natural substances. Although it is true that during the progress of the synthetic industry, a considerable part of the vegetable substances was no longer used, at present, due to the adverse effects of a high quantity of synthetic drugs, as well as due to the great demand for pharmaceutical products. Less harmful and more natural, there is a remarkable growth of pharmacological remedies made, for the most part, with substances of vegetable origin (Rodríguez et al., 2004).

Application of gender ethnomedical Erythrina on several continents of the world. Pacific Islands and Polynesia: Rotuma, Solomon Islands, Samoa, Tonga, Buka Islands, Papua New Guinea Islands, Marquesas Islands and New Caledonia; Islands of the Indian Ocean: Rodriguez Islands; Africa: Cameroon, Kenya, Rwanda, Senegal, Tanzania, Nigeria, Guinea, Uganda Zimbabwe; America: Argentina, Brazil, Cuba, Mexico, Guatemala, Panama and Peru; Asia: China, Taiwan, Philippines, Malaysia, Thailand, India, Nepal, Indonesia and Andaman Islands.

It is interesting to appreciate the similarity in the medicinal use of Erythrina species among all the inhabitants of the world. Many of the activities referred to for Cuban species, by Roig and the Alain and León brothers, have also been reported for other regions of the world, such as antifebrile, emenagogue, and analgesic activity (Prieto et al., 2002).

Erythrina Americana, of the Leguminosae family (Fabaceae), has been studied for its high content of alkaloids in seeds with its pharmacological activity. This species contains alkaloids erisovina, erisodina, erisopina and a- and ß-eritroidina, which are tertiary bases. While other alkaloids with similar pharmacological activity are quaternary salts. (Ibarra et al., 2011) 
The plant organs of the species Erythrina most used by traditional medicine are the bark and leaves, which are reported almost in equal percentage (33\% and $31 \%$, respectively). The roots, seeds, and flowers are also organs used by the population, although less frequently $(12,10$ and $8 \%$, respectively). Other parts used are the branches, the stem (and its bark), the fruits and the whole plant. The use of the sap of the plant was reported for the Erythrina variegata and has been used in New Caledonia for infertility treatments in women (Pino, 2004).

The genus Erythrina crista-galli L. is characterized by an antioxidant, astringent shell, with tanning and healing properties, this shell was used ancestrally to combat the pain caused by chronic diseases, nerves, anxiety, insomnia and spasms in general. Likewise, its seed was applied as a powerful poison for rodents and other animals harmful to man, in addition to fishing (University of Illinois, 2002). According (Gratieri-Sossella et al., 2008), a form of reproduction of Erythrina crista-galli L. for different uses is by stakes herbaceous collected from young plants, with less than 1 year of age.

According to the interview that was made to Ayón (2016), it is explained that one of the main protection mechanisms that allow the ceibo (Erythrina crista-galli L.) to reach maturity is that in its juvenile state, in the fourth part near the 150 years of life that it has, its trunk is totally covered with strong conical spines, short and thick. It does so because being a tree that holds a lot of liquid in its trunk, its wood is soft but strong enough to protect itself from rodents that try to rip its bark. With these thorns it prevents them from damaging it in its growth process, years later in winter, it is covered by abundant leaves, large velvety-looking red-purple flowers and white petals that may turn pink. Its fruit is a dark brown, hanging capsule, from which sprout the seeds, which are then dispersed by the wind. What does not take the breeze is a kind of wool that is born between the branches and that is usually collected to fill pillows, generally, but it is not used for fabrics, for being of short extension. May arrives and that wind that dispersed its seeds now takes away its leaves. The giant decides to undress to save energy. "The ceibo is one of the few species that performs its process of photosynthesis (converts light energy into chemistry) from its trunk."

For Camaqui (2012), the decoction of the leaves of the ceibo (5 leaves for a bottle of water) is used in bathrooms and washings to cure piles, sores, and wounds. This same cooking serves for washing and/or fomentation stops the bleeding of wounds and cuts. A proven remedy against seizures, cramps, nervous excitement, colic, neuralgia, and other painful diseases is to take a pot of Ceibo bark (about the size of a large finger for a jug of water).

Ceibo bark should not boil more than three minutes. The baths of the seat with the decoction of the shell or dry bark of the trunk of the Ceibo (of the size of a big finger for a bottle of water), are used in the cure of the vaginal flows, "white flowers", piles, prostatitis (inflammation of the prostate). These same baths act against gonorrhea or gonorrhea and the chance. The crushed fresh crust and applied in a poultice, heal the wounds and bites of animals. The infusion or mate of the bark of Ceibo (the size of a large finger) and four coca leaves, in a jug of boiling water, stop diarrhea. The alcohol in which a piece of the bark of this tree has macerated for seven days, using in frictions alleviates muscular pains or "makhurkha", bone pain and rheumatic pains (Camaqui, 2012).

According to what was researched in the article by Esteban (2013), ceibo has very good benefits for regenerating tissues, to fight joint pains and has even sedative and narcotic properties, so it should be used with caution when it comes to using internally. The best of this vegetable is usually in the crust. The ceibo has good analgesic properties for joint pain, the bark of the ceibo works very well for joint problems such as rheumatism or arthritis. To take advantage of its sedative properties, the ideal is to prepare steam baths and use them directly on the affected area.

It is an effective remedy for sores and wounds, the ceibo has regenerative properties for the skin. For this same reason, you can prepare a decoction with the bark and apply it externally for the healing of wounds, sores, scars, etc., even serves as a seated bath to combat hemorrhoids. It is used as a sedative, but we must be very careful with the internal use of ceibo since it has deep narcotic and sedative properties. That is why, if you want to consume the infusion, it should be in moderate quantities. In that case, it is good as a tranquilizer, to combat anxiety and also as a sleeping plant. The crushed bark and applied as a poultice, heal the wounds and bites of animals. It serves against throbbing pains to apply to internal sores in the mouth or sore throats (the product of angina, for example) can be gargle or swish with the preparation made with the bark (Esteban, 2013).

Zambrano, T. Y. M., Vera, O. P. G., Plaza, C. L. M., \& Farfan, R. M. (2019). Recovery of ancestral knowledge of the use of leaf and bark towards royal ceibo. International Journal of Life Sciences, 3(1), 41-47. https://doi.org/10.29332/ijls.v3n1.257 


\section{Materials and Methods}

Different materials were used to prepare the material, shown in table 1

Table 1

Material preperation

\begin{tabular}{clll}
\hline \multicolumn{5}{c}{} & \multicolumn{2}{c}{ Materials } \\
& \multicolumn{1}{c}{ Material } & \multicolumn{1}{c}{ Specifications } & Origin \\
\hline Quantity & Ceibo leaves & Remedy with healing potential & Ceibo tree \\
15 & Water & and bleeding controller. & Source of water \\
\hline
\end{tabular}

Source: (Gorozabel et al., 2018)

Experimentation was carried out to prepare $1 \mathrm{~L}$ of remedy to wash wounds, stop bleeding and promote the healing of wounds by cuts and burns, for which $1.25 \mathrm{~L}$ of water and 15 leaves of ceibo are placed in a pot. cooking for 30 minutes, and then let it stand for 3 hours. Once it has cooled down and placed in a glass container properly covered. The amount needed depending on the condition is used.

Table 1

Amount needed depending on the condition

\begin{tabular}{|c|c|c|c|}
\hline \multicolumn{4}{|c|}{ Materials (for 1 poultice) } \\
\hline Quantity & Material & Specifications & Provenance \\
\hline $\begin{array}{c}250 \mathrm{gr} \\
1\end{array}$ & $\begin{array}{l}\text { ceibo bark } \\
\text { Liencillo }\end{array}$ & $\begin{array}{l}\text { Remedy with healing potential and } \\
\text { bleeding controller. }\end{array}$ & $\begin{array}{l}\text { Ceibo tree } \\
\text { Canvas }\end{array}$ \\
\hline
\end{tabular}

Source: (Gorozabel et al., 2018)

The bark of the tree is harvested, weighed and crushed very well on a bunker with the grinding stone, until a sticky paste is obtained. It is then placed on the lily and applied to the wound.

\section{Results and Discussions}

The resin of the cortex was applied on the outside of the forearm to 30 students who were doing agricultural work and were exposed to solar radiation for 2 hours, some with minor injuries such as cuts and scrapes, others with burst blisters and superficial burns, The following results were obtained are shown in Table 2.

Table 2

Burst blisters and superficial burns

\begin{tabular}{lccc}
\hline \multicolumn{4}{c}{ Ceibo bark plaster } \\
\hline & Immediate & relief Subsequent relief & Scarring \\
\hline Wounds & 0 & 2 & 2 \\
\hline
\end{tabular}

Source: (Gorozabel et al., 2018)

As results, it was obtained that 2 students who presented wounds by light cuts of a machete in the hand were washed with the remedy of ceibo leaves and then the plaster was applied to promote its healing, this process started from the day of the cut. shows the healing time in Table 3. 
Table 3

Healing time

\begin{tabular}{lccc}
\hline \multicolumn{4}{c}{ The remedy of ceibo leaves } \\
\hline \multirow{2}{*}{ Condition } & \multicolumn{3}{c}{ Scarring } \\
\cline { 2 - 4 } & Immediate & relief Posterior relief & 13 \\
Scratches & 13 & 2 & 16 \\
Ampoules & 14 & 1 & 2 \\
Blisters burst & 1 & 1 & \\
Sunburn & 4 & & \\
\hline
\end{tabular}

Source: (Gorozabel et al., 2018)

Of the 30 students analyzed, 13 with scrapes, 16 with blisters, 2 with blisters burst and 5 with superficial burns on the face caused by exposure to the sun. We proceeded to wash the affected parts with the remedy of ceibo leaves, obtaining immediate relief to the discomfort. In the case of sunburns on the face, it was washed 2 times, allowing the water to dry on the face.

Based on the results obtained, 2 students who had cut wounds with machetes on their hands were washed with the ceibo leaf remedy and then the plaster was applied to promote their healing, this process began on the day of the cut. Concordant with the cited literature (Esteban, 2013). It is indicated that the ceibo has regenerative properties for the skin. For this same reason, you can prepare a decoction with the bark and apply it externally for the healing of wounds, sores, scars, etc.

Of the 30 students analyzed, 13 with scrapes, 16 with blisters, 2 with blisters burst and 5 with superficial burns on the face caused by exposure to the sun. We proceeded to wash the affected parts with the remedy of ceibo leaves, obtaining immediate relief to the discomfort. In the case of sunburns on the face, it was washed 2 times, allowing the water to dry on the face. Concordant with the cited literature (Esteban, 2013). It is indicated that the crushed bark and applied in the form of a poultice, heal the wounds and bites of animals. The remedies that use leaves and tree bark of royal ceibo are functional for the relief, healing and control of bleeding in wounds, cuts, burns, sores, blisters and minor skin conditions, cooked or crushed to be applied as plaster or lotion.

The recovery of ancestral knowledge on the preparation and use of natural remedies is necessary to counteract skin conditions that occur both inside and outside the home, with elements that are at hand as the components of the tree of the royal ceibo of the countryside manabita.

\section{Conclusion}

The social contribution of the results lies in the fact that in doing this work the youth is shown the use of the ceibo as a medicinal product and we are recovering the ancestral knowledge. The cultural contribution requires the diffusion of the ancestral knowledge of our ancestors that is currently unknown by the new generations, but which is very important for the handling of diverse daily situations using the natural elements that we have at our fingertips like the leaves and bark of the Ceibo tree that also constitutes an icon of the Montuvia culture from our aboriginal races, the Picuz and the Mantas.

The economic contribution of the results consists of promoting micro businesses for the preparation of lotions and remedies using the ceibo tree. This work does not harm the ecosystems of the royal ceibo since the extraction of the leaf and part of the bark is done strictly for healing purposes.

\section{Acknowledgments}

The authors thank the students who are currently investigating how to recover the healing methods with the real Ceibo.

Zambrano, T. Y. M., Vera, O. P. G., Plaza, C. L. M., \& Farfan, R. M. (2019). Recovery of ancestral knowledge of the use of leaf and bark towards royal ceibo. International Journal of Life Sciences, 3(1), 41-47. https://doi.org/10.29332/ijls.v3n1.257 


\section{References}

Ayón, J. (2016). Wonders of the royal ceibo. (DE Universe, Interviewer)

Camaqui, A. (2012). Interculturalmedicine.Obtained from Uses of ceibo in traditional medicine: http://medicinaintercultural.org/cd/recetas-de-medicina/usos-del-ceibo-en-medicina-tradicional

Esteban, J. (2013). Medicinal properties of the ceibo. Obtained from Plant to heal: https://www.plantasparacurar.com/propiedades-medicinales-del-ceibo/

González-García, K., Gonzalez-Lavaut, JA, González-Guevara, J., \& Prieto-Gonzalez, S. (2005). Genus Erythroxylum: analysis of scientific information. Buenos Aires Pharmaceutical Act,24 (2), 284. http://www.latamjpharm.org/trabajos/24/2/LAJOP_24_2_6_1_33D1Y9VDM0.pdf

Gratieri-Sossella, A., Petry, C., \& Augusto Nienow, A. (2008). Propagação da corticeira do banhado (Erythrina crista-galli L.)(Fabaceae) pelo processo de estaquia. Revista Árvore, 32(1). https://www.redalyc.org/html/488/48813376018/

Ibarra Estrada, E., Pacheco Sánchez, M., García Mateos, R., San Miguel Chávez, R., Ramírez Valverde, G., \& Soto Hernández, R. M. (2011). Actividad antioxidante de alcaloides de Erythrina americana Miller. Revista fitotecnia mexicana, 34(4), 241-246. http://www.scielo.org.mx/scielo.php?script=sci_arttext\&pid=S018773802011000400005

Lozano, E. C., \& Zapater, M. A. (2010). El género Erythrina (leguminosae) en Argentina. Darwiniana, 179-200. http://www.ojs.darwin.edu.ar/index.php/darwiniana/article/viewFile/18/9

Pico, J. (2010). A study on plant species in the Botanical Garden. The Technique, 6(13).

Suley, PR, Prieto-González, S., Pérez-Rodríguez, ME, \& Molina-Torres, J. (2004). Genus Erythrina: Source of secondary metabolites with biological activity. Acta Farm. Buenos Aires, 23 (2), 252-258. http://www.latamjpharm.org/trabajos/23/2/LAJOP_23_2_5_3_5CCQ1E589W.pdf

University of Illinois (2002). Board of Trustees NAPRALERT Database, Program for Collaborative Research in the Pharmaceutical Sciences, University of Illinois at Chicago USA. Illinois: University of Illinois. 


\section{Biography of Authors}

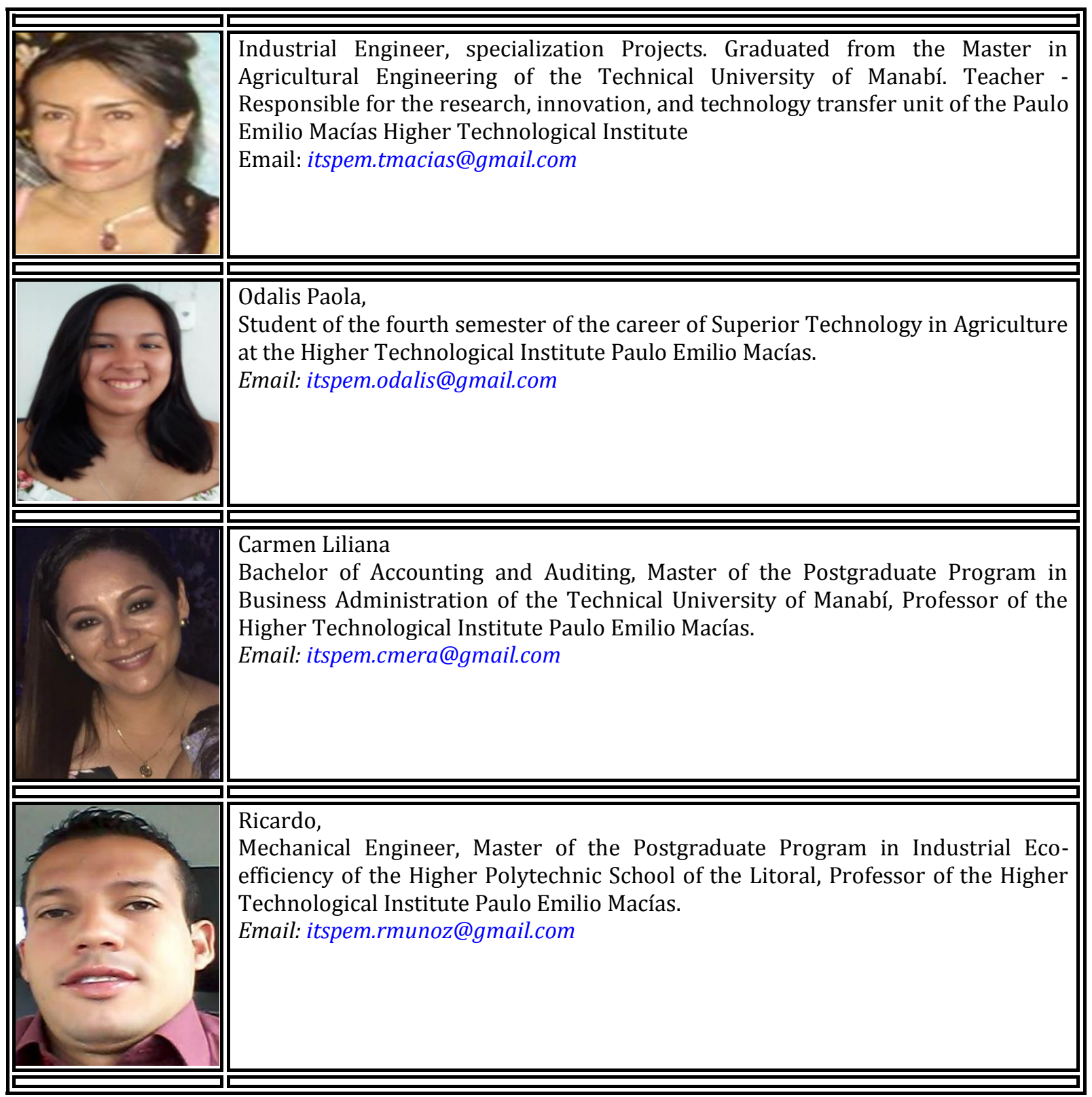

Zambrano, T. Y. M., Vera, O. P. G., Plaza, C. L. M., \& Farfan, R. M. (2019). Recovery of ancestral knowledge of the use of leaf and bark towards royal ceibo. International Journal of Life Sciences, 3(1), 41-47. https://doi.org/10.29332/ijls.v3n1.257 